\title{
o lírico-ciborgue de Angélica Ereitas: googlear para simular
}

Luciéle Bernardi de Souza1

Luciane Bernardi de Souza2

\section{Primeiras conexões}

O GÊNERO LÍRICO, APENAS PELO FATO DE EXISTIR (PRINCIPALMENTE NA CONTEMPORANEIDADE), RESISTE E É resistência, torna-se uma revolucionária arte do contemplar, do refletir, do estranhar e do sentir. O poema traz um olhar avesso para o mundo, um olhar diferenciado, e nos induz à suspensão de atividades cotidianas e utilitárias para, em um dado momento do dia, subverter, através da leitura (ou audição) de versos, a massa amorfa de ações práticas que insiste em preencher, mecanicamente, cada minuto do nosso dia.

O poema também nos instiga a buscar aquilo que falta para o encontro com o outro (e com nós mesmos), para cobrir

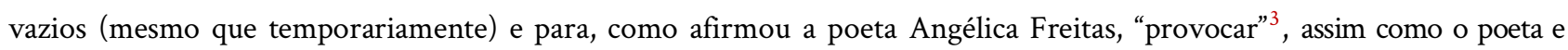
pensador Octávio Paz afirmou “O poema deve provocar o leitor: obrigá-lo a ouvir -a ouvir-se”.

Nesse sentido, a concepção de arte da pesquisadora Lucia Santaella ${ }^{5}$ está em consonância com a afirmação da autora Angélica Freitas. Santaella advoga a existência de uma arte inconformada com o estabelecido, uma arte que problematiza e é ela mesma um problema, arte ousada por estar no território privilegiado da liberdade, da imaginação e dos encontros possíveis. Ao defender este estatuto da arte, Santaella tem em mente as práticas poéticas (e artísticas de forma geral) originadas em ambientes virtuais. As novas, e cada vez mais presentes, tecnologias de comunicação corroboram para uma maior difusão de informações, notícias, conhecimentos, mas também podem ser usadas para criar juntamente com o humano. Para Santaella,

Os meios de nosso tempo estão nas tecnologias digitais nas memórias eletrônicas, nas hibridizações dos ecossistemas com os tecnossistemas e nas absorções inextricáveis das pesquisas científicas pela criação científica, tudo isso abrindo no artista e literato horizontes inéditos para a exploração de territórios inatos a sensorialidade e sensibilidade ${ }^{6}$.

Tendo em vista o processo de criação poética nesse território fértil, a rebeldia implícita no gênero lírico faz com que haja o estabelecimento de uma relação imediata com a sua contemporaneidade, seu contexto de produção. Formalmente mutante e inconformado, o gênero lírico ultrapassa o verso, mescla-se com a narrativa, perde a rima, ganha outros ritmos, traz imagens que são histórias e evidencia processos híbridos de composição. Sempre em crise a partir da modernidade, o gênero torna-se

\footnotetext{
${ }^{1}$ Doutoranda no Programa de Pós-Graduação em Literatura da Universidade Federal de Santa Catarina (UFSC). Contato: lucielebernardi@gmail.com

${ }^{2}$ Doutoranda no Programa de Pós-Graduação em Literatura da Universidade Federal de Santa Catarina (UFSC). Contato: lucibernardi@gmail.com

${ }^{3}$ Em entrevista no site do Canal Cultura:

http://jconline.ne10.uol.com.br/canal/cultura/literatura/noticia/2012/11/06/angelica-freitas-a-literatura-deve-provocar62599.php e reafirmada em um questionamento feito no espaço Delfos-PUCRS no dia 30/05/2016.

${ }^{4}$ PAZ, O. O arco e a lira. São Paulo: Cosac Naify, 2012, p. 314.

${ }^{5}$ SANTAELLA, L. Linguagens líquidas na era da mobilidade. São Paulo: Paulus, 2007, p. 31.

${ }^{6}$ Ibidem, p. 330.
} 
amigo de artes que requerem sua presença no palco, no livro-objeto, no espaço digital; o poema torna-se a própria

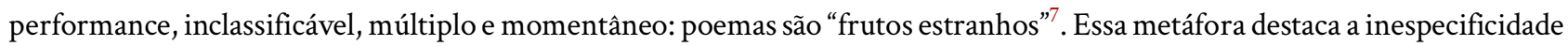
da arte contemporânea, especialmente do gênero poético, que está no desconfortável lugar do inclassificável e do mutável. Considerando a potencialidade de se reinventar constantemente, o poeta e crítico literário Marcos Siscar afirma que "A poesia está em crise; de certo modo continua em crise" ${ }^{8}$. Ao contrário de ver nesta constatação um problema, para o autor, é esta crise que impulsiona a existência da poesia desde a modernidade.

Neste trabalho, essa crise é pensada a partir da poética provocativa que parte da reflexão sobre três poemas pertencentes à obra um útero é do tamanho de um punho $(2012)^{9}$, da poeta Angélica Freitas. Além de tradutora, Angélica é autora de obras como Rilke Shake (1997) e Canções de atormentar (2020), participou de antologias poéticas e publicou, em coautoria com Odyr Bernardes, uma novela gráfica intitulada Guadalupe (2012). A obra um útero é do tamanho de um punho (2012) traz, já pelo título, o mote central da obra: a mulher. Essa pauta é comum na obra da autora, que versa sobre estereótipos relacionados ao gênero feminino, utilizando-se do humor e do sarcasmo para pensar e problematizar o que é ser mulher. Sem medo de incomodar e trazendo um diálogo forte com técnicas modernistas e temas relacionados ao universo "da mulher", especialmente da mulher lésbica, a obra um útero é do tamanho de um punho (2012), além de inúmeras outras interpretações e reações possíveis, provoca um tensionamento dos discursos machistas e misóginos presentes em nossa sociedade. Vale mencionar que a Assembleia Legislativa de Santa Catarina, na representação do deputado Jessé Lopes (PSL), apresentou uma moção de repúdio ao livro quando ele fazia parte da lista de leituras obrigatórias do vestibular de 2021 da Universidade Federal de Santa Catarina (UFSC).

Desta tão polêmica obra, foram escolhidos três poemas que conformam a sua quinta parte -a obra é composta por sete partes no total. Esta quinta parte recebe o nome de 3 poemas com auxílio do google. Tais poemas, intitulados a mulher vai, a mulher pensa e a mulher quer, contêm a peculiaridade de materializar um curioso eu-lírico que, pela inusitada integração humano-máquina (pois escritos com auxílio do Google, como o título faz referência), arriscamos, para melhor compreender tal encontro, nomear de maneira mais adequada. Substituindo o "eu" pelo "ciborgue", tem-se um acoplamento que nega o "eu soberano" da modernidade, pois não é nem a máquina, nem totalmente humano, mas um complexo agenciamento entre os dois.

Com relação aos três poemas em questão, a autora utiliza o termo "googlagem" para se referir ao seu processo de composição poético. Em um artigo publicado na revista eLyra, Angélica Freitas explica o que entende por "googlagem”: um procedimento de composição poética que "mistura Google e colagem" ${ }^{10}$. A explicitação da autora sobre seu processo poético, que nasce de uma brincadeira curiosa para saber o que o "Google" achava que uma poesia não era, corrobora com projetos poéticos que pensam a autoria de forma coletiva, colaborativa e híbrida. Assim, a voz lírica, ao encontrar-se inserida no contexto contemporâneo, abdica de sua significação enquanto categoria clássica, pensada e apreciada em correntes teóricas tradicionais que refletem sobre o gênero poético, compreendido como impassível de substituição ou mistura e centrado em um eu soberanamente individual e portador de "inspiração". Na criação poética aqui em questão, o eu-lírico perde o "eu” e torna-se uma voz lírica-poética plural, polifônica, ciborgue.

Fruto da relação entre o humano e a máquina, a análise de tais poemas propiciam o pensar sobre a criação poética via uma ontologia ciborgue (múltipla, livre da busca moderna de uma totalidade e transcendência), como propõe a filósofa Donna Haraway, "O ciborgue é nossa ontologia; ele determina nossa política" ${ }^{11}$. Temos, hoje, uma ontologia fortemente ligada às

${ }^{7}$ GARRAMUÑO, F. Frutos estranhos: sobre a inespecificidade na estética contemporânea. Rio de Janeiro: Rocco, 2014.

${ }^{8}$ SISCAR, M. Poesia e crise. Campinas: Editora Unicamp, 2010, p.32.

${ }^{9}$ FREITAS, A. Um útero é do tamanho de um punho. São Paulo: Cosac Naify, 2012, p.67-72.

${ }^{10}$ FREITAS, A. A mulher é: uma googlagem. eLyra: Revista da Rede Internacional Lyracompoetics, v.7, n.6, 2016 , p. 354.

${ }^{11}$ HARAWAY, D J. "Manifesto ciborgue: ciência, tecnologia e feminismo-socialista no final do século XX”. In: Silva, Tomaz T. (Org.). Antropologia do ciborgue: As vertigens do pós-humano. Belo Horizonte: Autêntica, 2000 [1985], p.37. 
práticas políticas do corpo híbrido, ontologia não mais calcada apenas no humano, sobretudo no humano-autor. Com o processo poético que ocorre entre o humano e a máquina, explicita-se também uma criação que parte de um material discursivo já existente anteriormente no Google: frases digitadas por usuários que se tornam versos em uma obra literária. Nessa relação, portanto, modifica-se o estatuto sobre a autoria e da propriedade "originária" dos versos advinda de um autor individual, evidenciando o processo de compartilhamento na composição: o google fornece os enunciados relacionados à pesquisa, a autora os ordena, estrutura, monta, conformando o poema. Esse processo que ensaia uma relativa diluição da autoria única nos faz lembrar a afirmação de Michel Foucault, pensador que, juntamente com Roland Barthes, problematizou a questão da autoria, mais especificamente da função-autor no discurso e na crítica literária:

Podemos imaginar uma cultura em que os discursos circulassem e fossem recebidos sem que a função autor jamais aparecesse. Todos os discursos, qualquer que fosse o seu estatuto, a sua forma, o seu valor, e qualquer que fosse o tratamento que se lhes desse, desenrolar-se-iam no anonimato do murmúrio. ${ }^{12}$

É importante ressaltar duas considerações com relação a esta afirmação. A primeira diz respeito ao seu possível uso para refletir sobre a criação, a autoria em meio digital e a multiplicidade de discursos que anulariam o discurso oficial do autor como único e legítimo. Essas são questões válidas, uma vez que os poemas são compostos por várias vozes advindas do Google, mas estruturados pela voz lírica humana, em um processo conjunto. A segunda questão refere-se especificamente à criação, que é realizada com o auxílio da web, mas não é feita totalmente na web, articulando o analógico e o digital. Quando se fala em "analógico", refere-se à parte humana que entra nessa relação, que traz a marca autoral de Angélica Freitas, fundamental para compreender a obra estudada aqui, o que não torna anônima. Há autoria, uma autoria coletiva (via Google) somada a articulação da poeta Angélica Freitas. Há, portanto, imbricação, negociação de sentidos e construção conjunta, relativizando o estatuto da criação poética individual.

Para não cair em equívocos, também é importante explicitar o ponto de partida quando falamos em ciborgues. A palavra ciborgue pode estar carregada de imagens "futuristas" ligadas a robôs e androides, reminiscências do final do século XX, imagens que têm pouca relação com o ciborgue pensado contemporaneamente, que está longe de tais estereótipos e mais ligado ao modo como nos relacionamos intensamente com aparatos tecnológicos.

Há, inegavelmente, novas subjetividades que surgem da aproximação entre o humano e a máquina (representada pelo computador e expandida pela internet), como pode-se constatar na manifesta nos três poemas mencionados, pois há uma sensibilidade que cria com a máquina. Autora cria com a máquina, gerando uma voz lírica também ciborgue. Esta diferente maneira de configurar o sensível, de criar, através do uso da ferramenta de busca Google, diz muito sobre a relação da poeta consigo, com seu leitor e com a sociedade, afinal, há a ênfase em uma aliança profícua entre humano e máquina, não importando mais a diferenciação de quando começa um e termina outro, mas sim a relação estabelecida e o que é gerado a partir dela.

Para o desespero dos temerosos que (ainda) querem "guardar" o gênero lírico longe dos bytes, assim como da colagem e da montagem (advindas das Vanguardas Europeias, sobretudo do Dadaísmo, Cubismo e Futurismo), por considerarem tais aproximações inadequadas, contaminadas (há maior contrassenso ao pensar sobre um gênero mutante?), nos perguntamos sobre as motivações para a autora lançar mão desta ferramenta e sobre os frutos advindos deste encontro. Como o poetizar ciborgue e seu processo de criação questiona o eu-lírico tradicional? Por que os "frutos estranhos" deste poetizar se tornam

${ }^{12}$ FOUCAUlT, M. O que é um autor? Tradução de José A. Bragança de Miranda e António Fernando Cascais. Lisboa: Passagem, 1992, p. 70. 
importantes para analisar a simulação da realidade na sociedade contemporânea? Essas são algumas perguntas que tentaremos responder. Passemos agora para uma rede de conexões importantes para aprofundarmos a reflexão sobre a mencionada experiência ciborgue-poética.

\section{Desenvolvendo outras conexões}

Antes do comentário analítico que articula o processo de criação e a simulação do mundo via poema, é fundamental compreender um pouco do mecanismo de funcionamento de pesquisa do Google para que haja uma melhor compreensão dos poemas, dentro do escopo teórico escolhido.

Quando nos conectamos em rede, estamos dentro de um espaço cibernético que é uma extensão da realidade empírica que a conforma concomitantemente. Como afirma Martha Gabriel, "somos on e off-line ao mesmo tempo, simbioticamente, formando um ser maior que o nosso corpo/cérebro biológico, nos expandindo para todo tipo de dispositivo e abrangendo outras mentes e corpos"13. Além de sabermos que o Google é a maior ferramenta de busca na internet atualmente, há algumas peculiaridades que devem ser mencionadas, como, ao realizar o login em algum de seus sites parceiros (Gmail, Youtube), há uma "transmissão" de informações do que você procura no site principal (Google) e de sites que visita para o suporte do Google. Corroborando com tais afirmações, Francisco Yus, pesquisador da área, afirma que há uma personalização aguda do buscador para cada um dos usuários, propondo fontes de resultados: "o Google estuda o costume e o rendimento dos usuários e produz resultados personalizados"14. Por exemplo, se você digitar no site de busca "cursos de inglês", poderá receber no seu e-mail, "misteriosamente", sugestões de sites de cursos em língua inglesa, escolas que oferecem tal serviço. Isso porque o site armazena dados e informações ligadas às pesquisas que realizadas e faz relações com o lugar de onde pesquisamos, nosso histórico de pesquisa salvo, dentre outras variantes. O mecanismo de procura por sites relacionados a um assunto que você tem interesse, elenca por relevância (sites mais visitados), por patrocínio e outros fatores gerados por uma série de mecanismos que buscam fornecer os resultados mais “úteis” para você, incluindo, obviamente, propagandas e similares. É isso que declara a pesquisadora Fátima Hassan "Desde que o Google adotou a busca semântica, o Mapa ou Gráfico do Conhecimento, uma base semântica de conhecimento tem sido utilizada para organizar informações sobre pessoas reais, lugares e coisas." ${ }^{15}$

Importante, portanto, compreender que, assim como a linguagem, o sistema de busca não é neutro, bem como não é absolutamente individual, mas traz traços de um sujeito no mundo e modifica a forma como ocorre a comunicação e até mesmo criações.

Dito isso, pode-se, através do nome da seção do livro em que os três poemas estão, verificar que há a explicitação de como foram feitos os poemas selecionados: são "três poemas feitos com o auxílio do google”. O leitor, desde o princípio da leitura, é chamado a compactuar com uma leitura que mobiliza conhecimentos pouco habituais para o gênero poético; é provocado a compreender que o eu-lírico tradicional se modificou quando se aliou ao Google, e é a partir desta aliança que surgirão os poemas. O Google, por sua vez, representa uma “voz coletiva”, a "nossa” voz, sendo portador de múltiplas subjetividades simultâneas.

${ }^{13}$ GABRIEL, M. Educ@r: a (r)evolução digital na educação. São Paulo: Saraiva, 2013, p. 58.

${ }^{14}$ Y us, F. Putting relevance at centre stage in all research on human activity on the Internet. Relevance: Discourse and Translation. Warsaw. Polônia, set. 2012, p. 05. Disponível em: < https://personal.ua.es/francisco.yus/site/stage.pdf $>$. Acesso em: 12, maio, 2021.

${ }^{15}$ HASSAN, F C. O mecanismo de busca do Google e a relevância na relação sistema-usuário. Revista Digital do Programa de Pós-Graduação em Letras da PUCRS, Porto Alegre, v. 8, n. 1, janeiro-junho 2015, p. 98. 
Os três poemas são compostos por versos longos, trazem aspectos narrativos e não possuem rimas. Os versos impactam por acumulação e repetição, procedimento anafórico que acaba deixando inquestionável o mote de cada poema (vai, pensa e quer). Os títulos dos poemas repetem a sentença “a mulher”, e eles só se diferem pela soma de um verbo diferente em cada um. Há, portanto, a repetição da estrutura sintática e a acumulação dessa repetição, portando pequenas (mas importantes) modificações nas orações, como já mencionado: "a mulher vai”, "a mulher pensa” e "a mulher quer". Os três poemas estão grafados com artigo inicial em minúscula, explicitando uma quebra de normas gramaticais e mostrando a aproximação com o modo como se digitam habitualmente/informalmente as procuras no Google, gerando uma aproximação linguística com o público leitor e reafirmando o lugar de onde partiram os versos.

O primeiro poema, intitulado "a mulher vai”, apesar de conter o verbo no presente do indicativo, pode ser compreendido como um "ordenamento" do que a mulher deve ou não fazer (pensar e querer nos outros dois). O verbo transitivo indireto deveria, sintaticamente, estar acompanhado da preposição "a" ou "para", no sentido de alguém que se desloca para algum lugar, movimenta-se. Aqui há a manifestação de coloquialidade, de imediatismo, que se comprova também pela falta de pontuação, pois o complemento do verbo é transcrito na forma frasal presente na fala cotidiana. No plano do conteúdo, há a colagem de ações que são habituais: "a mulher vai se casar, ter filhos, cuidar do marido e das crianças" (vs.13) ou "vai se arrepender até a última lágrima” (vs. 17), geralmente sem a preposição. Constata-se que apenas cinco dos 21 versos possuem preposição. Isso faz com que o poema tenha um tom prosaico, o mesmo tom das buscas na internet, no Google, pois acredita-se que, pela maneira como são conformados os versos, isso se deve a interferência do Google enquanto "buscador" de frases, ipsi litteris, escritas deste mesmo modo pelos/as usuários/as. Foi este movimento que permitiu uma sequência impactante e repetitiva de frases que contêm clichês, estereótipos advindos do senso-comum, que foram os "mapeados" e disponibilizados na procura no momento que foi digitado "a mulher vai...". Tais frases, mudam de suporte e, ao entrarem para a página do poema, no livro, nos lembram que foram ordenadas pela mão humana.

Tematicamente, o poema traz uma visão inicial que mostra a mulher como ser que realiza atividades cotidianas, como "vai ao cinema" (vs.1), ou tenta subverter o olhar machista quando "a mulher vai ao trabalho e deixa o homem na cozinha" (vs. 25). Porém, na grande maioria dos versos, há a sólida construção do estereótipo da mulher biológica/reprodutora, pois são versos ligados à biologia, mantendo a imagem clássica e utilitarista da mulher enquanto corpo reprodutor, como pode-se constatar nos seguintes versos: "a mulher vai ovular" (vs. 3), "vai passar nove meses com uma criança na barriga” (vs. 10), "a mulher vai realizar um ultrassom” (vs. 11), "a mulher vai casar, ter filhos, cuidar do marido e das crianças” (vs. 13). Ao trazer tais estereótipos, o lírico-ciborgue mostra algo além de a mulher ser esse reduzida a um ser "biológico" ou mesmo culturalmente ligado ao ato de "ser mãe", e o faz justamente enfatizando tal caracterização. Esse olhar além do dito é a possibilidade revelada pelo procedimento irônico, que se vale do dito para mostrar no não-dito. Neste poema, a última ação da mulher revela um desejo que parece banal, mas que diz respeito a uma restrição existente em países como o Afeganistão, onde direitos tão básicos como os de uma mulher estrangeira dirigir um carro parecem distantes: "a mulher vai poder dirigir no Afeganistão” (vs. 29). Há a revelação de um desejo, uma rápida fuga das frases clichês, verdadeiros estereótipos de gênero materializados em versos, mas é uma fuga melancólica, que almeja apenas o mínimo: dirigir um carro.

Essa visão sobre o que a mulher "vai (fazer)", se "atualiza" quando compreendida enquanto fato inserido na composição de um poema através da criação ciborgue. Essa aliança é quem faz a mediação entre o mundo real e o virtual, inserindo o leitor neste jogo em que ele reconhece o discurso do senso comum ao mesmo tempo que o recebe (e talvez se reconheça também?), não via um jornal, um artigo, uma pesquisa ou entrevista, mas por via poética.

Os poemas "a mulher pensa" e "a mulher quer" foram criados através do mesmo procedimento, da mesma maneira que o primeiro: através da aliança entre humano e máquina, com a ordenação das frases encontradas que "completavam" o enunciado principal inserido pela autora no espaço de pesquisa do site. O resultado foi a construção de imagens que explicitam aspectos misóginos e revelam a tensão de querer e pensar em uma sociedade visivelmente machista. Como já mencionado, a ironia é um mecanismo utilizado para compor o poema, ao trazer o que "a mulher pensa" e "a mulher quer", o lírico-ciborgue 
mostra o que ela "realmente" pensa e quer, esse lirismo-ciborgue plasma o coletivo machista presente no Google, simula e replica tal coletivo com intenção crítica, avaliativa, contestatória.

Nos dois poemas há imagens de uma mulher que "quer" ser submissa ("a mulher quer ser amada", "um macho que a lidere", "quer conquistar um sujeito"); ponderada ("pensa muito antes de fazer besteira”, "pensa no que poderia ter acontecido"); do lar ("pensa que pode se dedicar integralmente à carreira", "quer cuidar os filhos, o sujeito e o lar", "a mulher quer casar"); fútil e consumista ("a mulher pensa em roupas, crianças , viagens, passeios” , "a mulher pensa não só em roupa, mas no cabelo, na maquiagem", "a mulher quer um cartão de crédito", "a mulher quer um cara rico"), frágil e sensível ("a mulher pensa que a culpa foi dela", "a mulher pensa com o coração", "a mulher pensa emocionalmente", " a mulher quer que um cavalheiro cuide dela”) e histérica (" a mulher quer mexer no seu e-mail”). Os enunciados que compõem o poema são compilados pela autora, trazem sua marca estrutural e linguística da fonte web, porém, semanticamente, eles têm o potencial, através da ironia, de afirmar justamente o contrário o além do que afirmam, produzindo novos sentidos. Como Linda Hutcheon sustenta, "a ironia parece ser o principal mecanismo retórico para despertar a consciência do leitor" ${ }^{16}$.

A sobreposição de imagens, ao final da leitura dos três poemas em sequência, impacta pela acumulação de clichês preconceituosos advindos da "pesquisa”. Como revelado pela conjunção humano-máquina, a máquina nos traz uma opinião "coletiva”, capaz de nos mostrar o já constatado (no mundo real), mas de maneira que chame a atenção (pela escolha e organização humana), que gere reflexão, justamente por estar em um poema (não em um jornal, por exemplo) e pela maneira como é realizado o procedimento criativo.

Frisa-se que, apesar da obra de Angélica Freitas problematizar a questão da heteronormatividade, dando espaço para mulher lésbica e suas experiências, em nenhum verso encontramos a referência de uma mulher para a outra, ou seja, a pesquisa direcionou a construção da mulher através da ótica masculina, uma ótica hegemonicamente machista. Pode-se pensar esta questão através da reflexão da poeta americana Adrienne Rich (2019 [1980]), inclusive traduzida por Angélica Freitas, que no ensaio intitulado "Heterossexualidade compulsória e existência lésbica", explica o silenciamento das existências lésbicas relacionando-o à crença de um senso comum que torna invisíveis as vivências que fogem da heteronormatividade. Isso explicaria um "Google" direcionado (ou direcionando) a pensar/reproduzir a imagem da mulher via uma ótica machista e heteronormativa.

Corroborando com a questão de gênero pensada aqui, Judith Butler declara que "A linguagem é um conjunto de atos, repetidos ao longo do tempo, que produzem efeitos de realidade que acabam sendo percebidos como 'fatos"' 17 . De acordo com essa firmação, constata-se que, através do lírico-ciborgue, foi possível a "captação" de ações, de discursos que produzem fatos/atos e fazem parte de um mundo real-virtual, mas que não foram constatados individualmente em entrevistas ou mesmo coletivamente em pesquisas sociológicas. São esses efeitos de realidade que trazem e fazem os fatos, consolidados e construídos por discursos, mas também é a linguagem que pode subverter e trazer à tona a violência vigente em nossa sociedade, e a traz em prol de uma reflexão sobre esta própria violência. Essa mesma linguagem que constrói a ironia, mecanismo que faz parte de um processo comunicativo (intrínseco ao poema) e não apenas um "mecanismo estático a ser utilizado, mas nasce nas relações entre significados, e também entre pessoas e emissões e, às vezes, entre intenções e interpretações” ${ }^{18}$.

Por fim, ressalto o último verso presente no último poema da tríade: "a mulher quer se suicidar" (vs. 27). A ironia fica por conta da repetição de estereótipos, mas também da inserção de imagens como "a mulher quer tudo" (vs. 23) ou "a mulher quer se separar" (vs. 25), intercaladas com uma dose de realidade de uma outra ótica, que não parece ser a machista, como podemos constatar neste verso: "a mulher quer ser valorizada e respeitada" (vs.24). Afinal, apesar de querer respeito e querer, aliás,

${ }^{16}$ HUTCHEON, L. Uma teoria da paródia. Ensinamentos das formas de arte do século XX. Lisboa: Edições 70, 1987 , p. 47.

${ }^{17}$ BUTLER, J. Problemas de gênero: feminismo e subversão da identidade. Tradução de Renato Aguiar. Rio de Janeiro: Civilização Brasileira, 2010, p. 168.

${ }^{18}$ HUTCHEON, L. Teoria e política da ironia. Minas Gerais: Editora da UFMG, 2000, p. 30. 
"tudo", sua saída mais óbvia e imediata é o suicídio. Temos um viés crescente do preconceito e da violência no poema, o que conforma uma única (e última) alternativa “viável”: afinal, depois de tantas constatações a respeito da mulher, restará outra saída?

Os poemas analisados reafirmam a tensão que a linguagem, por pertencer ao mundo e revelá-lo, ao mostrar de maneira diferenciada o óbvio, estabelece com o mundo. É através da relação humano-máquina, uma relação fértil, materializada em forma poética, em linguagem, que vem à tona um discurso que potencializa a reflexão sobre práticas machistas e heteronormativas, excludentes de vivências e sensibilidades. Como Haraway afirma,

A escrita é, preeminentemente, a tecnologia dos ciborgues - superfícies gravadas do final do século XX. A política do ciborgue é a luta pela linguagem, é a luta contra a comunicação perfeita, contra o código único que traduz todo significado de forma perfeita - o dogma central do falogocentrismo. É por isso que a política do ciborgue insiste no ruído e advoga a poluição, tirando prazer das ilegítimas fusões entre animal e máquina. ${ }^{19}$

\section{Fios conectados, frutos gerados}

Analisados os poemas, é importante articular outras conexões profícuas para uma reflexão sobre o processo de escrita conformadora de um lirismo tão singular. Então serão retomados alguns conceitos relativos ao fazer poético, articulando máquina e humano.

Discussões sobre os limites entre a subjetividade e a objetividade, a máquina (e suas potencialidades) e o humano, eu e o outro, não são novas dentro dos Estudos Literários, Antropológicos e Sociológicos. No campo da Semiótica, da Comunicação e pela vertente dos Estudos Culturais, tais questões foram potencializadas com discursos de Donna J. Haraway ${ }^{20}$, Amber Case, Tomaz Tadeu, Katherine Hayles ${ }^{21}$ e Hari Kunzru. Donna Haraway, principal pensadora do conceito de "ciborgue", o definiu como um "um organismo cibernético, um híbrido de máquina e organismo, uma criatura de realidade social e também uma criatura de ficção. Realidade social significa relações sociais vividas, significa nossa construção política mais importante, significa uma ficção capaz de mudar o mundo"22. As discussões envolvendo tal interação tiveram seu auge nos anos 90 e, até hoje, levantam questionamentos e fecundos debates. Partindo da perspectiva de que não existe sujeito e subjetividade fora da história, da linguagem, da cultura e das relações de poder, Haraway afirma que o ciborgue deriva da interação entre dois elementos, dois "seres" e suas diferenciadas ontologias, de uma relação "em termos de fluxos e intensidades" ${ }^{33}$ (2000, p.14), pois estão "De um lado, a mecanização e a eletrificação do humano; de outro, a humanização e a subjetivação da máquina. É da combinação desses processos que nasce essa criatura pós-humana a que chamamos 'ciborgue”” ${ }^{24}$ (2000, p.12).

\footnotetext{
${ }^{19}$ HARAWAY, op.cit., 2000, p. 88.

${ }^{20}$ Vale lembrar que Donna Haraway, por sua reflexão e militância, por pensar o corpo enquanto uma autoconstrução, tornouse uma referência para uma geração de mulheres que se intitulam “ciberfeministas”. Tal geração que a tecnologia pode construir, através da interação com o humano, a identidade, a sexualidade e o gênero.

${ }^{21}$ Esta pensadora, muito influenciada por Haraway, levou a discussão para o campo literário, para a Teoria Literária, ao reivindicar o termo "literário" para produções, trabalhos que "interrogam contextos", como a coleção presente em: http://collection.eliterature.org/1/ . Acesso em 1/05/2021.

${ }^{22}$ Ibidem, p.36.

${ }^{23}$ Ibidem, p. 14

${ }^{24}$ Ibidem, p. 12.
} 
Somos uma nova geração de homo sapiens que, desde a pré-história, vem se modificando com diferentes tecnologias. Somos ciborgues enquanto pessoas contemporâneas e, Angélica Freitas, na opção de criar com a máquina, torna-se autoraciborgue, gerando, por conseguinte, um lírico-ciborgue. Não são necessárias próteses, basta a ligação humano-máquina para estar nesta condição.

Se "somos todos ciborgues" ${ }^{25}$, a criação deste lírico-ciborgue pode ser pensada, pelo material linguístico do poema e pela escolha de alianças (com a máquina), como uma oportunidade de explicitação pouco comum da persistência do machismo na sociedade hodierna. Neste trabalho, portanto, a discussão de gênero não é entendida tal qual o também profícuo pensamento (com relação à abolição de dicotomias de gênero) de Haraway, um mundo pós-gênero -via ciborgue, pois o empírico nos mostra que o discurso machista ainda é uma realidade ficcional-real-virtual, nos levando a um olhar atento sobre as questões de gênero, em especial na construção da mulher e seus estereótipos nocivos. Com isso, obviamente, de modo algum nega-se a possibilidade e existência real da não-binarização do ser, sobretudo dentro de uma ontologia ciborgue. Tal existência é um fato, mas salienta-se novamente que, pelo que revela a criação gerada pelo lírico-ciborgue neste trabalho, ainda há muito a ser pensado sobre o machismo e suas formas de opressão, e o ciborgue é meio para a constituição do fruto que mostra isso de uma maneira diferenciada, com humor e potencializado por esse humor. Os poemas analisados (re)apresentarão para o leitor um discurso arcaico e opressor que vivenciado em nossa sociedade, mas que é apresentado via um fluxo humano-tecnologia de fundo irônico, revelado pela referência à autoria. Eles trazem imagens sobre o que é ser mulher em uma sociedade machista.

Pode-se constatar que Angélica Freitas não possui receio de manifestar sua posição política no mundo e na vida, afinal, ela afirma que "tudo o que fizemos é político, até não ser político é ser político" ${ }^{26}$. Esta afirmação permeia sua obra, pois há uma reivindicação de lugar e de voz que, justamente por seu trabalho poético (em especial o modo como o realiza), traz a palavra em sua máxima potência, ressoando muitas vozes que compõem as imagens "da mulher". Ativa na internet por meio de diversos canais de comunicação (Twitter, Facebook, Instagram), e pensando que ser escritor(a) hoje é existir em redes sociais e outros meios de comunicação, estar mais exposta a cada dia, a autora é questionada sobre sua visão frente a este mundo de virtuais possibilidades, sobre o potencial moral, político e artístico que a internet proporciona, sobre as fronteiras entre o virtual e o "real", ou o virtual enquanto uma extensão do real. Compreendendo este panorama com relação à autora, é importante mencionar que, para assimilar a ironia presente nos poemas, é fundamental incluir a situação referencial e autoral presente na obra, mas com cuidado para não cair em hermenêuticas relacionadas à autoria, ao autor como portador de uma "verdade" única e revelada por meio do biografismo autoexplicativo. Como Hutcheon (2000) define, a ironia é um mecanismo retórico que opera em muitos níveis, com vários elementos (como o contexto, a intenção, os marcadores discursivos), e traz uma exigência para quem a cria e para quem a interpreta, "A ironia não é ironia até que seja interpretada como tal" ${ }^{27}$. Portanto, nem sempre a ironia acontece como planejado, muitas vezes ela falha, dependendo sobretudo do seu contexto. Ao propor dita conceitualização do que é uma mulher, através das palavras de outrem (de inúmeras pessoas) presentes no Google, contesta-se tal discurso, ridiculariza-o, pois há uma avaliação e denúncia do que é ser uma mulher na sociedade brasileira contemporânea.

Nesse processo, é importante ter em mente que a linguagem faz parte do mundo ao mesmo tempo que o compõe. Para Angélica Freitas, essa curiosidade de criar linguisticamente com a máquina nasceu (corriqueiramente) da seguinte maneira

Queria saber como eram escritos, com que palavras, com que autoridade. Um dia coloquei no Google "A mulher é" - vai que obtivesse alguma resposta interessante. Fui copiando e colando os resultados para talvez montar um poema mais tarde. Ao ler o material que havia juntado,

\footnotetext{
${ }^{25}$ Ibidem, p.36-37.

${ }^{26}$ Em conversa aberta no espaço Delfos-PUCRS no dia 30 de maio, 2016.

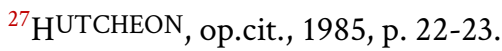


percebi que nem fazia falta dar-lhe uma "ordem". Não havia como ficar menos ou mais absurdo do que aquilo. Permaneceu inédito. Foi um teste, o embrião da série "Três poemas com o auxílio do Google” (“A mulher vai”, “A mulher quer”, “A mulher pensa”), que acabou sendo publicada no livro ${ }^{28}$.

Como constatou-se, há o elemento do acaso como parte do processo criativo, que surge por ludicidade e curiosidade, mas, sobretudo, expõe-se a criação como montagem, e só possível pela cocriação. Há um humano criador com a máquina, um encontro, um fluxo entre duas esferas que originam o ciborgue.

Ainda ligada às condições pragmáticas de produção, a arte mostra o que, muitas vezes, é escamoteado pela vivência cotidiana. Ela realiza isso por meio da mediação de um conteúdo, uma objetivação (histórica e social) presente em sua forma (como é construído o poema), incorporando em sua estrutura artística as antinonimias sociais. Portanto, nega o que incorpora e é por sua negação, pela organicidade crítica e tensa, que o poema se materializa. Os três poemas de Angélica Freitas podem ser vistos a partir desta perspectiva, uma vez que incorporam enunciados "machistas", evidenciando criticamente tais discursos criadores de realidade. A ironia consiste em trazer o machismo para dentro do poema e devolvê-lo para a sociedade em forma de reflexão, mesmo correndo o risco de não ter o efeito de sentido desejado. Para a pesquisadora Beth Brait, a ironia pode ser uma "forma de argumentação indireta contra algum alvo" ${ }^{29}$, e pode-se visualizar exatamente este movimento irônico nos poemas em questão, movimento que só é possível ao considerar os elementos extratextuais, o contexto em que o poema provavelmente irá circular (que prevê a concretização do efeito irônico), absolutamente ligado a quem enuncia.

O registro do "senso comum" de uma sociedade marcada pelo machismo, vem à tona com a escolha da poeta quanto ao procedimento de escrita. Ao registrar esse machismo discursivo, dialoga e encontra correspondência na dimensão discursiva, sensível, de uma sociedade presente nas pesquisas do Google, explicitando o material linguístico familiar para grande parte de seus leitores, já que as frases são geradas por pessoas que utilizam esse conhecido site de pesquisa.

Angélica Freitas, como constatado por meio das análises dos poemas, utiliza-se do discurso machista justamente para denunciá-lo, realiza ruídos no campo literário ao provocar o cânone da autoria poética individual, distanciada da máquina e vista como a única legítima, e faz isso ao gerar um lírico-ciborgue portador de uma voz coletiva. Para compreender tal ruído, é necessário mobilizar uma volta ao Romantismo enquanto estética fruto do individualismo moderno e calcada sobre esse pilar advindo da burguesia. Arlindo Machado, ao realizar uma discussão relacionando estética e informação (que vigorou com força na década de 1970 com a estética informacional), afirma que "O divórcio entre arte e tecnologia -se é que se trata de divórcio-, nasce com o romantismo e seus conceitos apaixonados sobre a genialidade individual e sobre o papel do imaginário na arte ${ }^{30}$. Para grande parte dos escritores românticos, portanto, há uma dissociação importante entre indivíduo imaginativo e tecnologia no que tange a criação poética, o que gerou uma distinção entre o belo e o útil, uma dicotomia que, como será visto, não se sustenta com relação aos poemas aqui estudados. Contrariamente, Haraway (2000 [1985]) já mencionava o sem limites entre natural e artificial, a dicotomia no fim do século XX, opondo-se a essa perspectiva romântica presente na criação poética

As máquinas do final do século XX tornaram completamente ambígua a diferença entre o natural e o artificial, entre a mente e o corpo, entre aquilo que se autocria e aquilo que é externamente criado, podendo-se dizer o mesmo de muitas outras distinções que se costumavam

\footnotetext{
${ }^{28}$ FREITAS, op.cit., 2016, p.354.

${ }^{29}$ BRAIT, B. Ironia e perspectiva polifônica . Campinas: Unicamp, 1996. Revista Famecos, Porto Alegre, n. 13, p. 68-82, dez. 2000, p. 57.

${ }^{30} \mathrm{M} A C H A D O, A$. Máquina e Imaginário: O desafio das poéticas tecnológicas. São Paulo, Editora da Universidade de São Paulo, 1993, p. 27.
} 
aplicar aos organismos e às máquinas. Nossas máquinas são perturbadoramente vivas e nós mesmos assustadoramente inertes. ${ }^{31}$

\section{Até a próxima conexão}

A poema, por ser comunicação, pode trazer uma nova para o que, muitas vezes, já é familiar (principalmente com relação ao conteúdo). Assim, pode-se pensar que o que nos é comum, cotidiano, nos foi mostrado de maneira diferente, nos fazendo, por isso, ter a possibilidade de reflexão sobre a simulação de uma realidade já comum, habitual, mas invocada de maneira diferenciada, crítica. O discurso contido nos poemas (e na sociedade) choca por nos mostrar o óbvio.

A arte, seja ela literária ou não, ao provocar no leitor mudanças de percepção sobre si, a vida e o outro, propicia o necessário estranhamento que deve reger as condições de percepção da realidade social, uma vez que esta se constitui como antagônica, permeada e gerada por impasses irresolutos que se modificam e se acentuam constantemente.

Mediante a análise dos poemas, constata-se que a máquina pode ser um elemento propulsor, participativo e efetivo na conformação da obra de arte transgressora, fértil em seu humor e provocativa em seu conteúdo. Angélica Freitas, mediante o processo criativo em 3 poemas com auxílio do google (2012), tensiona, colapsa limites, problematiza o conceito de autoria e refuta dualismos simplórios e conservadores quando o assunto é criação poética.

Por fim, a leitura e análise destes poemas, sobretudo o centramento neste novo e complexo agente enunciador, o "líricociborgue", desmistifica a máxima de que a arte contemporânea realizada com auxílio da tecnologia seria despolitizada e objetiva. Angélica Freitas eterniza o real-virtual, traz à tona o inverso desta afirmação ao elaborar uma arte politizada e subjetiva, que diz sobre o mundo e sobre a sociedade (via internet), resultado da expressão de uma nova ordem sensível que, todavia, ainda está em processo de compreensão. A arte sabe como desvelar a complexidade do mundo, rir do mesmo, ridicularizar o próprio humano que a constrói e mostrar o quanto, paradoxalmente, nosso pensamento ainda é arcaico e conservador, mesmo convivendo e fabricando a mais alta tecnologia, que deveria estar sempre a favor da informação, da aproximação e da alteridade.

\section{Referências bibliográficas}

BRAIT, Beth. Ironia e perspectiva polifônica. Campinas: Unicamp, 1996.

CAPARELLI, Sérgio; GRUSZYNSKI, Ana Cláudia; KMOHAN, Gilberto. Poesia visual, hipertexto e ciberpoesia. Revista Famecos, Porto Alegre, n. 13, p. 68-82, dez. 2000.

BUTLER, Judith. Problemas de gênero: feminismo e subversão da identidade. Tradução de Renato Aguiar. Rio de Janeiro: Civilização Brasileira, 2010.

FOUCAUlT, M. O que é um autor? Tradução de José A. Bragança de Miranda e António Fernando Cascais. Lisboa: Passagem, 1992.

FREITAS, Angélica. Um útero é do tamanho de um punho. São Paulo: Cosac Naify, 2012.

A mulher é: uma googlagem. eLyra: Revista da Rede Internacional Lyracompoetics, v.7, n.6, 2016.

\footnotetext{
${ }^{31}$ Haraway, op.cit., 2000, p. 42.
} 
HARAWAY, Donna J. "Manifesto ciborgue: ciência, tecnologia e feminismo-socialista no final do século XX". In: SILVA, Tomaz T. (Org.). Antropologia do ciborgue: As vertigens do pós-humano. Belo Horizonte: Autêntica, 2000 [1985].

GARRAMUNÕ, Florencia. Frutos estranhos: sobre a inespecificidade na estética contemporânea . Rio de Janeiro: Rocco, 2014.

GABRIEL, Martha. Educ@r: a (r)evolução digital na educação. São Paulo: Saraiva, 2013.

HUTCHEON, Linda. Teoria e politica da ironia. Minas Gerais: Editora da UFMG, 2000.

MACHADO, Arlindo. Máquina e Imaginário:O desafio das poéticas tecnológicas. São Paulo, Editora da Universidade de São Paulo, 1993.

RICH, Adrienne. Heterossexualidade compulsória e existência lésbica \&̇ outros ensaios. Rio de Janeiro: A Bolha, 2019.

SANTAELlA, Lucia. Linguagens líquidas na era da mobilidade. São Paulo: Paulus, 2007.

SISCAR, Marcos. Poesia e crise. Campinas: Editora Unicamp, 2010.

YUS, Francisco. Putting relevance at centre stage in all research on human activity on the Internet. Relevance: Discourse and Translation. Warsaw. Polônia, set. 2012. Disponível em < https://personal.ua.es/francisco.yus/site/stage.pdf > .Acesso em 12, maio, 2021.

Recebido em: 28/06/2021

Aceito em: 30/10/2021 